\title{
Visualizing Accounting Transaction Flows into Financial Statements
}

\author{
Daniel J. Jones, Assumption College, USA
}

\begin{abstract}
Professors who teach the introductory accounting course should ask themselves: "What are the core concepts that I wish to have my non-majors remember if I meet them at their ten-year alumni class reunion?" There is a fundamental logic to financial accounting. This teaching note presents foundational accounting concepts in a manner that enables readers to understand this logic. In doing so, it answers the question posed above.

The first half of the teaching note explains the purpose and elements of two primary financial reports: a balance sheet and an income statement. The second half presents the recording of several business transactions and traces their effect into a company's balance sheet and income statement. Designed for use early in an introductory accounting course, the teaching note enables students to develop a strong conceptual understanding of financial accounting.
\end{abstract}

Keywords: Financial Accounting; Introductory Accounting; Transaction Analysis; Financial Reports; Balance Sheet; Income Statement

\section{INTRODUCTION}

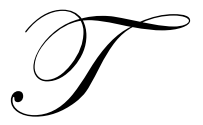

here are many entrepreneurs, managers, investors, and others with a keen interest in business who have never taken an accounting course. If one of them asked me to summarize the fundamentals of financial accounting in several pages, this teaching note would be my response. In a similar vein, there is an important question that guides my teaching in the introductory accounting course: "What are the foundational concepts that I wish to have my students remember if I met them at their ten-year class reunion?" This teaching note answers the question.

There is a fundamental logic to financial accounting. The purpose of this teaching note is to present elementary accounting concepts in a manner that enables readers to understand what I refer to as the profound simplicity of financial accounting.

\section{FINANCIAL ACCOUNTING FUNDAMENTALS}

The equation in Exhibit 1: The Accounting Equation is the foundation for financial accounting. It recognizes that the assets owned by an entity must always be equal to the claims on those assets.

\begin{tabular}{|c|c|c|c|c|}
\hline \multicolumn{5}{|c|}{ Exhibit 1: The Accounting Equation } \\
\hline Assets & $=$ & Liabilities & + & Owner' Equity \\
\hline $\begin{array}{l}\text { RESOURCES } \\
\text { owned by } \\
\text { the entity }\end{array}$ & $=$ & $\begin{array}{l}\text { CLAIMS on } \\
\text { the assets } \\
\text { by creditors }\end{array}$ & + & $\begin{array}{l}\text { CLAIMS on } \\
\text { the assets } \\
\text { by the owner }(s)\end{array}$ \\
\hline
\end{tabular}


Financial accounting presents financial information regarding an organization's business activities. The four primary financial statements that present this information are:

- a balance sheet

- an income statement

- a statement of changes in equity

- a statement of cash flows.

This teaching note covers two of the four statements: the balance sheet and the income statement. Purposes and alternative names for the balance sheet and income statement are presented below.

\begin{tabular}{|l|l|l|}
\hline Financial Statement & \multicolumn{1}{|c|}{ Purpose } & \multicolumn{1}{c|}{ Other Names } \\
\hline Balance sheet & $\begin{array}{l}\text { Statement presents financial position in } \\
\text { Assets = Liabilities + Owner's Equity format }\end{array}$ & $\begin{array}{l}\text { - Statement of Assets and Liabilities } \\
\text { - Statement of Financial Position }\end{array}$ \\
\hline Income statement & $\begin{array}{l}\text { Statement reports net income (profit) as } \\
\text { Net income = Revenues - Expenses }\end{array}$ & $\begin{array}{l}\text { - Profit \& Loss Statement (P\&L) } \\
\text { - Statement of Operations }\end{array}$ \\
\hline
\end{tabular}

A balance sheet reflects the accounting equation presented earlier in Exhibit 1: The Accounting Equation. A balance sheet presents information regarding the resources that an entity owns (assets) and the claims against those resources (liabilities and owner's equity) at a given point in time, normally at the end of a month or year.

The five types of accounts in financial accounting are described in Exhibit 2: Account Types Defined. Assets, liabilities, and owner's equity are presented in a balance sheet. The other two account types, revenues and expenses, represent changes in owner's equity. They are reported in an income statement.

\begin{tabular}{|l|l|l||}
\hline \multicolumn{2}{|c|}{ Exhibit 2: Account Types Defined } \\
\hline Account Type & \multicolumn{1}{|c|}{ Definition } & \multicolumn{1}{|c|}{ Examples } \\
\hline \hline Assets & RESOURCES owned by the entity & $\begin{array}{l}\text { Cash } \\
\text { Accounts Receivable }\end{array}$ \\
\hline Liabilities & CLAIMS on the assets by creditors & $\begin{array}{l}\text { Accounts payable } \\
\text { Loans payable }\end{array}$ \\
\hline Owner's equity & CLAIMS on the assets by the owner(s) & $\begin{array}{l}\text { Capital (for an unincorporated business) } \\
\text { Common stock (for a corporation) } \\
\text { Retained earnings (for a corporation) }\end{array}$ \\
\hline \begin{tabular}{|l|l|l||}
\hline Note: If the balance sheet were the only financial statement, there would be only the three account types above. \\
Since most organizations prepare income statements, two other account types are required: revenues \& expenses.
\end{tabular} \\
\hline \multirow{2}{*}{$\begin{array}{l}\text { Revenues } \\
\text { Expenses }\end{array}$} & $\begin{array}{l}\text { Increases in owner's equity from the operating } \\
\text { activities of the entity during the period. }\end{array}$ & $\begin{array}{l}\text { Consulting revenue } \\
\text { Dividend revenue } \\
\text { Gains can be considered to be revenues. }\end{array}$ \\
\hline $\begin{array}{l}\text { Decreases in owner's equity from the operating } \\
\text { activities of the entity during the period. }\end{array}$ & $\begin{array}{l}\text { Advertising expense } \\
\text { Rent expense } \\
\text { Losses can be considered to be expenses. }\end{array}$ \\
\hline
\end{tabular}

An income statement presents information regarding revenues and expenses during a given period. The statement presents net income (profit) as revenues minus expenses. Negative net income is referred to as a net loss. 


\section{RECORDING TRANSACTIONS \& VISUALIZING INFORMATION FLOWS}

Accounting transactions are business activities that affect the financial statements. The following two rules guide the recording of transactions:

- When recording any transaction, the accounting equation must always be kept in balance.

- In order to keep the accounting equation in balance, a transaction must affect at least two accounts.

Exhibit 3: Balance Sheet presents the July 31, 2012 balance sheet for Vann Company. Because ending account balances for one period represent beginning balances for the next period, the balance sheet in Exhibit 3 provides beginning account balances for Vann Company for the month or August.

\begin{tabular}{|c|c|c|c|c|}
\hline & Exhibi & Balance Sheet & & \\
\hline & $\begin{array}{r}\mathrm{V} \\
\mathrm{E} \\
\text { As }\end{array}$ & $\begin{array}{l}\text { Company } \\
\text { ce Sheet } \\
\text { y } 31,2012\end{array}$ & & \\
\hline$\underline{\text { Assets }}$ & & $\begin{array}{l}\text { Liabilities \& Owner's Equity } \\
\text { Liabilities }\end{array}$ & & \\
\hline Cash & $\$ 17,470$ & Accounts Payable & $\$ 0$ & \\
\hline Accounts Receivable & 1,000 & Total Liabilities & & $\$$ \\
\hline Land & $\underline{13,000}$ & Owner's Equity & & \\
\hline & & $\begin{array}{l}\text { V. Vann, Capital } \\
\text { Total Owner's Equity }\end{array}$ & $\$ 31,470$ & 31,470 \\
\hline Total Assets & $\$ \underline{\$ 31,470}$ & Total Liabilities \& Owner's Equity & & $\$ 31,470$ \\
\hline
\end{tabular}

In order to illustrate the recording of transactions, Vann Company August transactions are presented in Exhibit 4: August Transaction Listing. Exhibits 3 and 4 serve as the basis for preparing Exhibit 5: Visualizing Transaction Flows into Financial Statements on the following page.

\begin{tabular}{|ll|}
\hline $\begin{array}{l}\text { Date } \\
\text { Aug. } 1\end{array}$ & $\begin{array}{l}\text { Transaction Description } \\
\text { Vann Company loaned } \$ 10,000 \text { cash to Brown Company, to be repaid on November } 1 \text {. On November } 1 \text {, Brown } \\
\text { Company will repay the } \$ 10,000 \text { principal amount plus } \$ 300(\$ 10,000 \times 3 \%) \text { interest. }\end{array}$ \\
Aug. 15 & $\begin{array}{l}\text { Vann Company completed a service order for } \$ 2,400 \text {. Customer paid that amount in full. } \\
\text { Aug. } 31\end{array}$ \\
$\begin{array}{l}\text { Interest on the loan is } \$ 100(1 \% \text { of } \$ 10,000) \text { for each month of the loan. This is recorded as a } \$ 100 \text { increase in } \\
\text { Interest Receivable and a } \$ 100 \text { increase in Interest Revenue for the month of August. }\end{array}$ \\
Aug. 31 & $\begin{array}{l}\text { Vann Company received an invoice for August telephone service for } \$ 110 . \text { Vann will pay the invoice in three weeks. } \\
\text { The Daily Planet ran an advertisement for Vann Company in the August } 31 \text { edition of the newspaper. The } \$ 500 \text { cost } \\
\text { of the ad will be paid on September } 20 .\end{array}$ \\
\hline
\end{tabular}

Exhibit 5: Visualizing Transaction Flows into Financial Statements reflects the maxim, "a picture is worth a thousand words." It enables students to envision the effect of business transactions on a company's income statement and balance sheet.

The spreadsheet in Exhibit 5 reflects beginning account balances and transactions for Vann Company for the month of August. In addition, Exhibit 5 presents the flow of accounting information from the spreadsheet into the company's income statement and balance sheet.

July ending balances for assets, liabilities, and owner's equity are carried forward as beginning balances in the August spreadsheet. Because they are temporary accounts, July revenue, expense, and drawings balances have been closed into the company's only permanent * owner's equity account, V. Vann Capital. Because of this, August beginning balances are zero for all revenue, expense, and drawing accounts. [*Note: A corporation has at least two permanent accounts: one or more for paid-in capital and another for retained earnings.] 
Exhibit 5: Visualizing Transaction Flows into Financial Statements

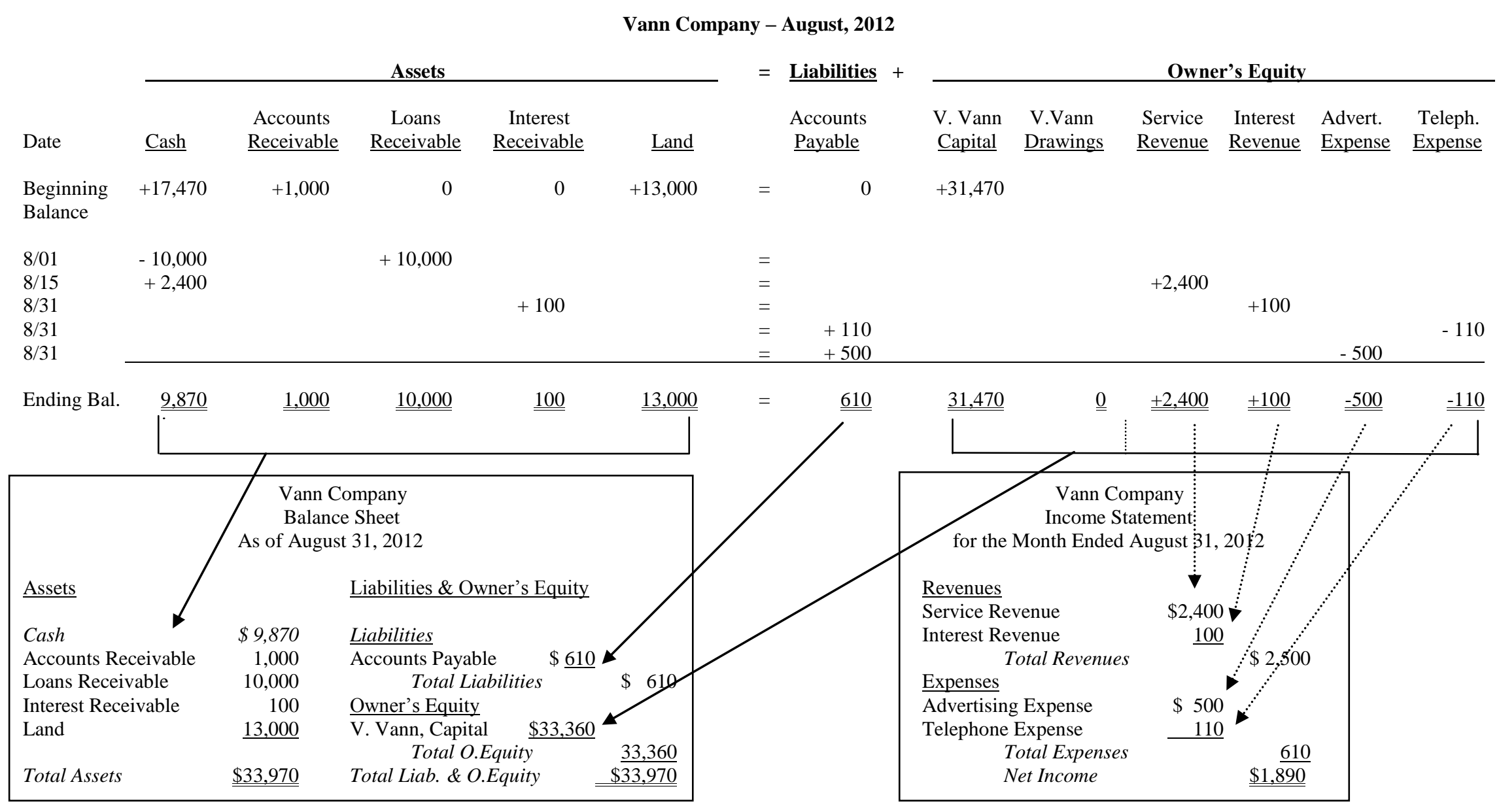




\section{AUTHOR INFORMATION}

Daniel J. Jones, CPA, MBA, is an Assistant Professor of Accounting at Assumption College, USA. He teaches financial accounting, cost accounting, and personal finance courses. E-mail: dajones@assumption.edu 
NOTES 